\title{
Solvent Effects on the Uv-Visible Absorption Spectra of Some New Thienylazo-Thiazole and Thienylazo-Thiophene Dyes
}

\author{
Ehab Abdel-Latif*, Asmaa M. Mansour and Ebrahim Abdel-Galil \\ Chemistry Department, Faculty of Science, Mansoura University, 35516 Mansoura, \\ Egypt.
}

$\mathbf{F}$

ACILE synthesis of various thienylazo-thiazole and thienylazo-thiophene dyes were described. 2-Amino-5-(2-thienylazo)-thiazole dyes 5 and 6 have been constructed by coupling the diazotized 2-aminothiophenes $1 \mathrm{a}$ and/or $1 \mathrm{~b}$ with 2-amino-4-phenylthiazole (3) and/or 2-(N-methylamino)-4-phenylthiazole (4). Coupling of 2-aminothiophene derivative 1a with 2-acetyl-3-oxo-N-phenylbutanethioamide (7) affected cleavage of one acetyl group to furnish the corresponding 2-acetyl-2-thienylazo-thioacetanilide dye 8 which has been utilized as a precursor for the construction of different 3-methyl-2-substituted-4-thienylazo-thiophenes 10-13 through its treatment with the appropriate alpha-chlorinated reagents (namely; $\mathrm{MeCOCH}_{2} \mathrm{Cl}, \mathrm{PhCOCH}_{2} \mathrm{Cl}, \mathrm{ClCH}_{2} \mathrm{COOEt}$ and $\mathrm{ClCH}_{2} \mathrm{CN}$ ). The effect of solvent polarity on absorption spectra was investigated, as was the relationship between dye structures and absorption in the UV-visible region.

\section{Graphical Abstract}

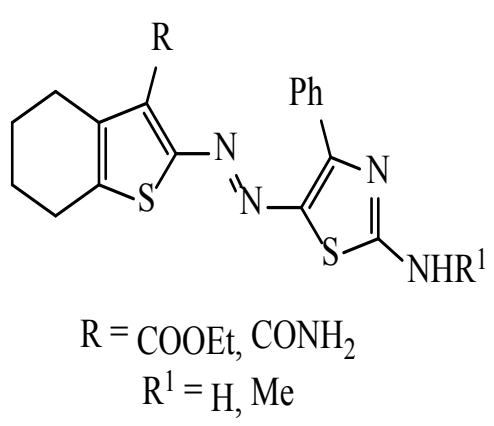<smiles>[Y]C(=O)c1sc(Nc2ccccc2)c(N=Nc2sc3c(c2C(=O)OCC)CCCC3)c1C</smiles>

$$
\mathrm{Y}=\mathrm{CH}_{3}, \mathrm{Ph}, \mathrm{OEt}
$$

Keywords: 2-Aminothiazoles, Diazo-coupling, Thienylazo-thiazoles, Thienylazo-thiophenes, UV-visible Absorption.

\section{Introduction}

Azo dyes are the most important class of colored compounds, accounting for more than $50 \%$ of all commercial dyes. They are synthesized by diazotization of a primary aromatic amine followed by diazo-coupling of the obtained diazonium salt with electron rich aromatic compounds [1,2]. Specially, heterocyclic azo derivatives are usually characterized by intense color, which promotes their application as dyes and pigments in various fields including textile and polymer industries [3,4]. Nitrogen and/or Sulphur heterocyclic azo dyes have been utilized in different fields such as color formers, printing [5], electronic photography, laser technology and solar energy conversion [6]. Such compounds have potential use in optical communications, frequency doubling and integrated optics [7]. Arylazo dyes of different heterocyclic moieties have been reported in the recent literature as the subject of intense research by chemists [8] and dye manufacturers [9]. Azo-thiophene and azo-thiazole derivatives have received significant attentions since they are applied in dye-sensitized solar cells and as efficient semiconducting materials [10-14]. In the present research article, we synthesized

*Corresponding author : E-mail : ehabattia00@yahoo.com 
successfully a series of thienylazo-thiazole and thienylazo-thiophene derivatives by utilization of 2-amino-4,5,6,7-tetrahydrobenzo[b]thiophenes as diazo-components and their diazo-coupling with 2-aminothiazoles and 2-acetyl-3-oxo-Nphenylbutane-thioamide as coupler components.

\section{Results and Discussion}

Gewald amino thiophene synthetic method<smiles>[R]CC#N</smiles>

has been utilized for the construction of 2-amino4,5,6,7-tetrahydrobenzo[b]thiophenes $1 \mathrm{a}$ and $1 \mathrm{~b}$ (Scheme 1). The title compound 1a [15] was prepared from cyclohexanone, ethyl cyanoacetate and elemental Sulphur in ethyl alcohol and triethylamine. The other title compound $1 \mathrm{~b}$ [16] was prepared by the same procedure using cyanoacetamide instead of ethyl cyanoacetate.

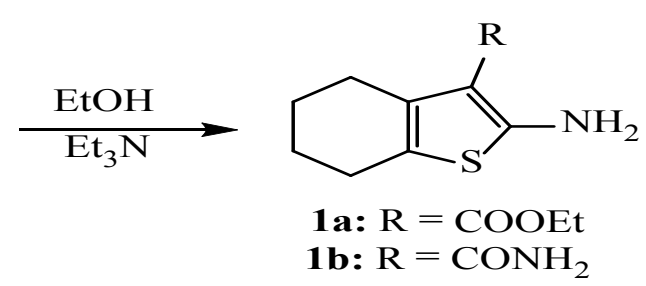

Scheme (1)

2-Amino-5-(2-thienylazo)-thiazole dyes 5 and 6 have been constructed by the electrophilic diazo-coupling reaction between 2-aminothiazole derivatives and the diazotized 2-aminothiophenes (Scheme 2). Diazotization of 2-aminothiophenes 1a and $1 \mathrm{~b}$ has been achieved by treatment with sodium nitrite and $\mathrm{H}_{2} \mathrm{SO}_{4} / \mathrm{AcOH}$ at $0-5^{\circ} \mathrm{C}$. The obtained diazonium sulphates 2 were coupled with 2 -amino4-phenylthiazole (3) and/or 2-(N-methylamino)4-phenylthiazole (4) in ethyl alcohol and sodium acetate to furnish the targeted 2-amino-5-(2thienylazo)-thiazole dyes 5 and 6 . The diazocoupling reaction proceeds at the most reactive site of thiazole nucleus, the fifth position of thiazole (C$5)$, for electrophilic substitution reaction.

The infrared spectra of 5-thienylazo-thiazole dyes 5 exhibited absorptions that are compatible with stretching vibrations of $\mathrm{N}-\mathrm{H}$ bond of the amino group in the region $v=3318-3264 \mathrm{~cm}^{-1}$. The carbonyl group of ester function in 5-thienylazothiazole dyes $5 \mathrm{a}$ and $6 \mathrm{a}$ has been absorbed at $\mathrm{v}=$ 1707 and $1688 \mathrm{~cm}^{-1}$, respectively. The carbonyl group of amide function in 5-thienylazo-thiazole dyes $5 \mathrm{~b}$ and $6 \mathrm{~b}$ has been absorbed at $\mathrm{v}=1660 \mathrm{~cm}^{-1}$.

The ${ }^{1} \mathrm{H}$ NMR signals of $6 \mathrm{~b}$ displayed two multiplet signals in the regions $\delta 1.71-1.75$ and 2.71-2.74 ppm for the protons of four methylene groups in the cyclohexane moiety. The singlet for three protons at $\delta 3.04 \mathrm{ppm}$ has been assigned for methyl group of $\mathrm{CH}_{3}-\mathrm{N}$ moiety. The multiplet and doublet signals at $\delta$ 7.47-7.56 and $8.22 \mathrm{ppm}$ referred to five aromatic protons and $\mathrm{NH}$. The singlet $\delta 7.70 \mathrm{ppm}$, integrated for two protons, indicated amide function $\left(\mathrm{CONH}_{2}\right)$.

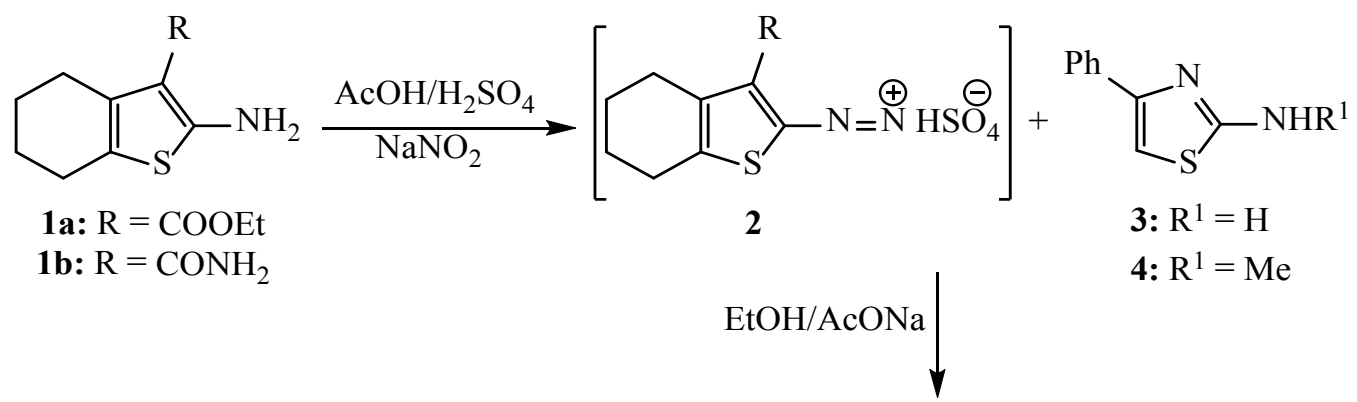

5a: $\mathrm{R}=\mathrm{COOEt}, \mathrm{R}^{1}=\mathrm{H}$

5b: $\mathrm{R}=\mathrm{CONH}_{2}, \mathrm{R}^{1}=\mathrm{H}$

6a: $\mathrm{R}=$ COOEt, $\mathrm{R}^{1}=\mathrm{Me}$

6b: $\mathrm{R}=\mathrm{CONH}_{2}, \mathrm{R}^{1}=\mathrm{Me}$<smiles>[R1]Nc1nc(-c2ccccc2)c(N=Nc2sc3c(c2[R])CCCC3)s1</smiles>

Scheme (2) 
2-Aminothiophene derivative 1a has been diazotized by nitrous acid $\left(\mathrm{NaNO}_{2}\right.$ and $\mathrm{H}_{2} \mathrm{SO}_{4} /$ $\mathrm{AcOH})$ to form the corresponding diazonium sulphate 2, which coupled with 2-acetyl-3-oxoN-phenylbutanethioamide (7) through JappKlingemann reaction conditions to furnish the corresponding 2-acetyl-2-thienylazothioacetanilide dye 8 as indicated in Scheme 3 . The diazo-coupling reaction proceeds in ethyl alcohol and sodium acetate and affected an acetyl group replacement. The structure of 8 finds support from its spectral analysis (IR and ${ }^{1} \mathrm{H}$ NMR).

The infrared spectrum of dye 8 showed the characteristic absorption bands of carbonyl groups of ester and acetyl functions at $0=$ 1705 and $1660 \mathrm{~cm}^{-1}$, respectively. The ${ }^{1} \mathrm{H}$ NMR spectrum displayed triplet at $\delta 1.39 \mathrm{ppm}$ and quartet at $\delta 4.43 \mathrm{ppm}$ for the protons of $\left(-\mathrm{O}-\mathrm{CH}_{2}-\right.$ $\mathrm{CH}_{3}$ ) group. The protons of cyclohexane moiety resonated as multiplet for four protons at $\delta 1.79$ $1.84 \mathrm{ppm}\left(-\mathrm{CH}_{2}-\mathrm{CH}_{2}-\right)$ and two triplet signals at $\delta$ 2.66 and $2.82 \mathrm{ppm}$ (two $-\mathrm{CH}_{2}$-). The singlet for one proton at $\delta 2.11 \mathrm{ppm}$ indicated the thiol form of this compound (-SH). The protons of methyl group $\left(\mathrm{O}=\mathrm{C}-\mathrm{CH}_{3}\right)$ was identified as singlet at $\delta$ $2.59 \mathrm{ppm}$. The five aromatic protons resonated as multiplet in the region $\delta 7.28-7.70 \mathrm{ppm}$. The singlet at $\delta 13.32 \mathrm{ppm}$ referred to the proton of imine function $(\mathrm{N}-\mathrm{H})$.<smiles>Nc1sc2c(c1C(=O)O)CCCC2</smiles>

$1 \mathrm{a}$

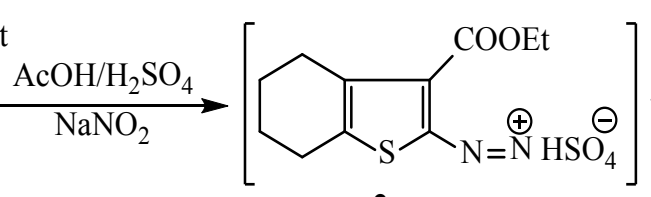

2<smiles>CC(=O)C(C(C)=O)C(=S)Nc1ccccc1</smiles>

7<smiles>C=CCC(C)OC(=O)c1c(N=NC(C(C)=O)C(=S)Nc2ccccc2)sc2c1CCCC2</smiles>

Scheme (3)

2-Acetyl-2-thienylazo-thioacetanilide dye 8 has been reacted with four types of alphachlorinated reagents (namely; chloroacetone, phenacyl chloride, ethyl chloroacetate and chloroacetonitrile) in boiling ethyl alcohol containing triethylamine to give the corresponding 3-methyl-2-substituted-4-thienylazo-thiophenes 10, 11, 12 and 13, respectively (Scheme 4).

The mechanistic scenario for the formation of these thiophenes involves initial alkylation of 8 with the alpha-chlorinated reagent to give the non-isolable thioether intermediates 9 followed by in situ heterocyclization through nucleophilic addition of methylene group to the carbonyl group and elimination of water molecule.

The chemical structures of thiophenes 10-13 were identified based on their correct spectral analyses. The infrared spectra of the constructed 4-thienylazo-thiophenes 10-13 exhibited the characteristic absorption of carbonyl function of ester near $v=1707 \mathrm{~cm}^{-1}$. The characteristic absorption of nitrile group (in the spectrum of 13) was identified at $2199 \mathrm{~cm}^{-1}$.

The 1H NMR spectrum of 4-thienylazothiophene dye 13 displayed a triplet at $\delta 1.34$ ppm and quartet at $\delta 4.31 \mathrm{ppm}$ for the protons of $\left(-\mathrm{O}-\mathrm{CH}_{2}-\mathrm{CH}_{3}\right)$ group. The protons of cyclohexane moiety resonated as multiplet for four protons at $\delta$ 1.82-1.84 ppm (- $\left.\mathrm{CH}_{2}-\mathrm{CH}_{2}-\right)$ and two triplet signals at $\delta 2.71$ and $2.82 \mathrm{ppm}$ (two $-\mathrm{CH}_{2}$-). The protons of methyl group (thiophene- $\mathrm{CH}_{3}$ ) was identified as singlet at $\delta 2.43 \mathrm{ppm}$. The five aromatic protons resonated as multiplet in the region $\delta$ 7.21-7.54 ppm. The singlet at $\delta 13.47 \mathrm{ppm}$ referred to the proton of imine function $(\mathrm{N}-\mathrm{H})$.

J.Text.Color. Polym. Sci., Vol. 15, No.1(2018) 


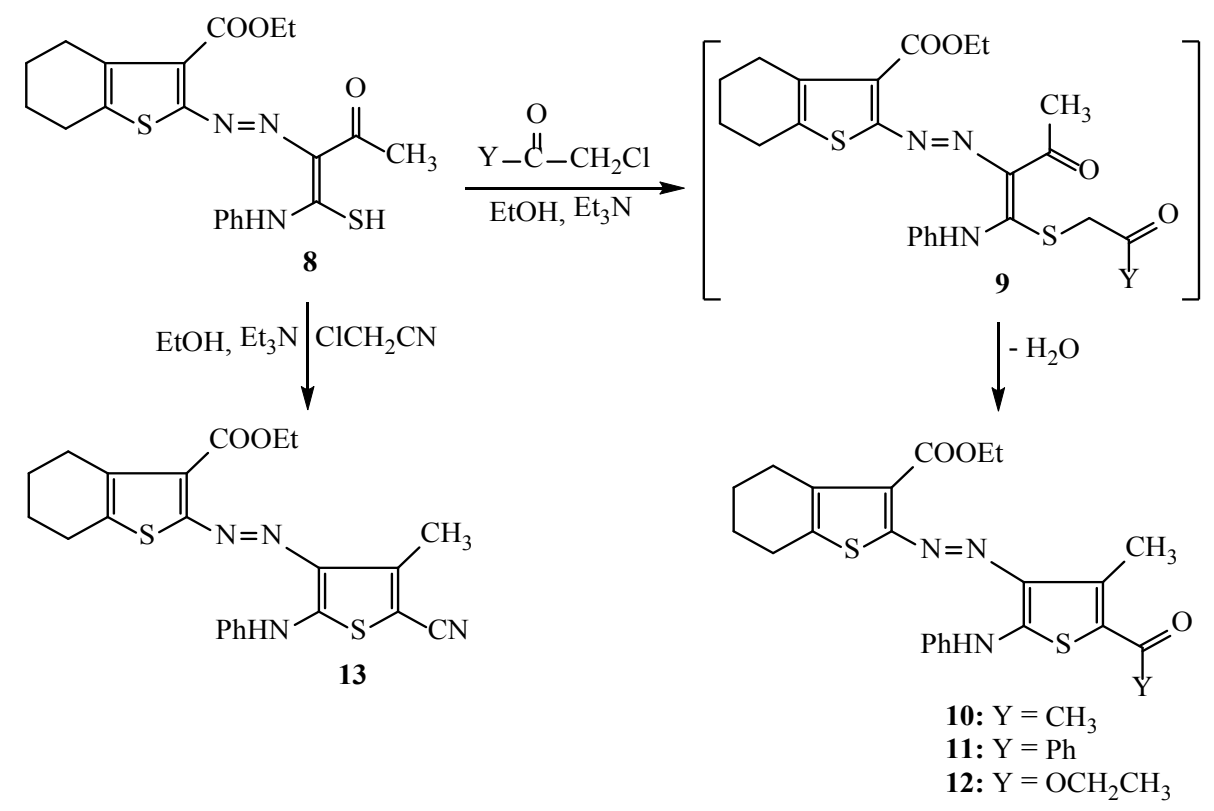

Scheme (4)

The solvent effect on the UV-visible absorption spectra

This part of essay studied the effect of solvent in UV-vis absorption bands of compounds 5, 6, 10, 11, 12 and 13. Using different solvents with different polarities leaded to a difference in both wavelength and absorption values. This is due to unequal perturbation of the ground and exited electronic state of molecule, which depends on the nature of the solute-solvent interactions. The effect of solvent on UV-visible absorption spectra have been screened for over the years in the literature. The photo-physical properties of a soluble dye are closely related to the nature of its environment, i.e. the shape, intensity, and maximum absorption wavelength. The UVvisible absorption of a dye solution depends mainly on the solvent-solute interactions and solvent nature [17-20].

Our unsaturated compounds have pi electrons, which had the ability to determine the electron sheath state through their excitation by absorbing the UV-visible light. The presence of oxygen, nitrogen and sulfur atoms provides n-electrons (non-bonding electrons) to our tested compounds, so electronic spectra arose from $\pi-\pi^{*}$ transition and $n-\pi *$ transition characteristic of the $-\mathrm{N}=\mathrm{N}-$ group. The solvent effect on spectra is primary dependent on the chromophore, the nature of transition and charge transfer absorption. Charge transfer obtained from donner to acceptor groups in organic molecules.

The main difference between compounds 5a and $5 \mathrm{~b}$ is the nature of substituent at the second position of thiophene moiety, ester group (COOEt) in dye $5 \mathrm{a}$ and amide group $\left(\mathrm{CONH}_{2}\right)$ in dye $5 \mathrm{~b}$. The presence of methyl group at the amino function characterizes the N-methylaminothiazole dye 6 from aminothiazole dye 5 . The absorption $\lambda \max$ values of these four aminothiazole dyes $5 \mathrm{a}, 5 \mathrm{~b}, 6 \mathrm{a}$ and $6 \mathrm{~b}$ were very close to each other. DMF solvent caused more bathochromic shift than acetone and methanol. The highest $\lambda_{\max }$ value observed for compounds $6 \mathrm{a}$ and $6 \mathrm{~b}$ at $530 \mathrm{~nm}$ in DMF.

Absorption spectra of compounds 10, 11, 12 and 13 were studied in three different solvents with different polarity with the aim of probing the effect of solvent polarity on electronic transitions. Using solvents with different polarity caused differences in electronic transitions, which resulted in variations in the absorption spectra. Compounds 10,11, 12 and 13 differ in the chemical structure according to the nature of substituent at position number 2 of the thiophene ring. 2-Cyano 4-thienylazothiophene dye 13, which has nitrile group $(-\mathrm{C} \equiv \mathrm{N})$ at the second position of thiophene, gave the highest $\lambda_{\text {max }}$ values at 514, 518 and $522 \mathrm{~nm}$ in the used solvents methanol, acetone and DMF, 
respectively. 2-Acetyl-4-thienylazothiophene dye 10 , which has acetyl group (-COMe), gave the second highest $\lambda_{\max }$ values at 460, 520 and 532 $\mathrm{nm}$ in methanol, acetone and DMF, respectively. 2-Benzoyl-4-thienylazothiophene dye 11, which contains benzoyl group (-COPh), displayed moderate $\lambda_{\text {max }}$ values near 432, 508 and $510 \mathrm{~nm}$ in methanol, acetone and DMF, respectively. Finally, 2-Ethoxycarbonyl-4-thienylazothiophene dye 12, which has ester group (-COOEt), displayed the lowest $\lambda_{\max }$ values near 414,422 and 422 $\mathrm{nm}$ in methanol, acetone and DMF, respectively. It is observed that DMF solvent caused more bathochromic shift than acetone and methanol due to polarity difference.

Tables 1 and 2 represented the values of wavelength $\left(\lambda_{\max }\right)$ for dyes $5,6,10,11,12$, and 13 . The UV-visible absorption spectra for these dyes are indicated in Figures 1 and 2.

TABLE 1. UV-visible absorption wavelength for dyes 5a, 5b, $6 a$ and $6 \mathrm{~b}$.

\begin{tabular}{|c|c|c|c|c|}
\hline Solvent & $5 a$ & $5 b$ & $6 a$ & $6 b$ \\
\hline Methanol & $\begin{array}{l}280.00 \\
330.00 \\
420.00 \\
514.00\end{array}$ & $\begin{array}{l}316.00 \\
358.00 \\
388.00 \\
510.00\end{array}$ & $\begin{array}{l}286.00 \\
338.00 \\
518.00\end{array}$ & $\begin{array}{l}230.00 \\
292.00 \\
330.00 \\
369.00 \\
518.00\end{array}$ \\
\hline Acetone & $\begin{array}{l}268.00 \\
306.00 \\
372.00 \\
516.00\end{array}$ & $\begin{array}{l}240.00 \\
269.00 \\
293.00 \\
312.00 \\
388.00 \\
512.00\end{array}$ & $\begin{array}{l}268.00 \\
358.00 \\
388.00 \\
520.00\end{array}$ & $\begin{array}{l}229.00 \\
254.00 \\
260.00 \\
410.00 \\
518.00\end{array}$ \\
\hline DMF & $\begin{array}{l}298.00 \\
334.00 \\
384.00 \\
524.00\end{array}$ & $\begin{array}{l}298.00 \\
356.00 \\
388.00 \\
522.00\end{array}$ & $\begin{array}{l}294.00 \\
352.00 \\
530.00\end{array}$ & $\begin{array}{l}298.00 \\
382.00 \\
530.00\end{array}$ \\
\hline
\end{tabular}

TABLE 2. UV-visible absorption wavelength for dyes 10, 11, 12 and 13.

\begin{tabular}{ccccc}
\hline Solvent & $\mathbf{1 0}$ & $\mathbf{1 1}$ & $\mathbf{1 2}$ & $\mathbf{1 3}$ \\
\hline \multirow{3}{*}{ Methanol } & 272.00 & 358.00 & & 268.00 \\
& 366.00 & 404.00 & 276.00 & 330.00 \\
& 460.00 & 432.00 & 414.00 & 436.00 \\
& & & & 514.00 \\
Acetone & 372.00 & 270.00 & 234.00 & 302.00 \\
& 520.00 & 370.00 & 278.00 & 342.00 \\
& & 508.00 & 312.00 & 518.00 \\
DMF & 284.00 & 270.00 & 422.00 & 328.00 \\
& 368.00 & 370.00 & & 386.00 \\
& 532.00 & 464.00 & 250.00 & 436.00 \\
& & 510.00 & 422.00 & 522.00 \\
\hline
\end{tabular}




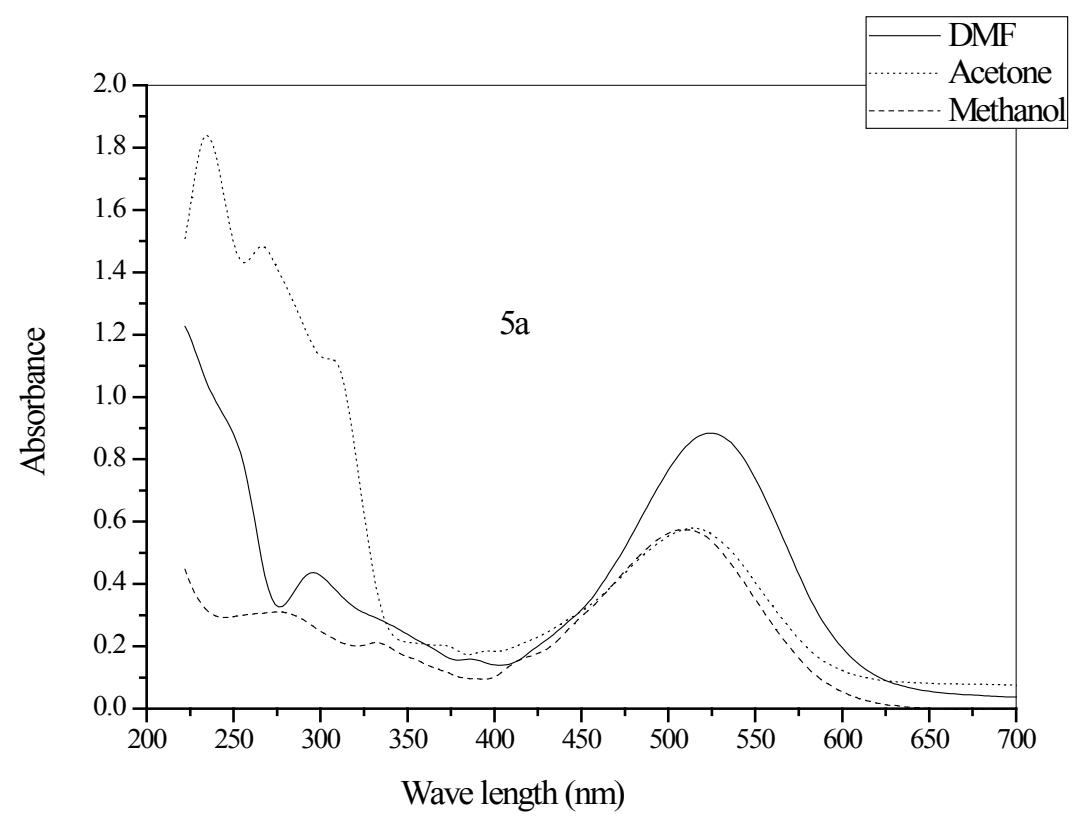

Fig. 1(a). UV-visible absorption spectra of dye $5 \mathrm{a}$.

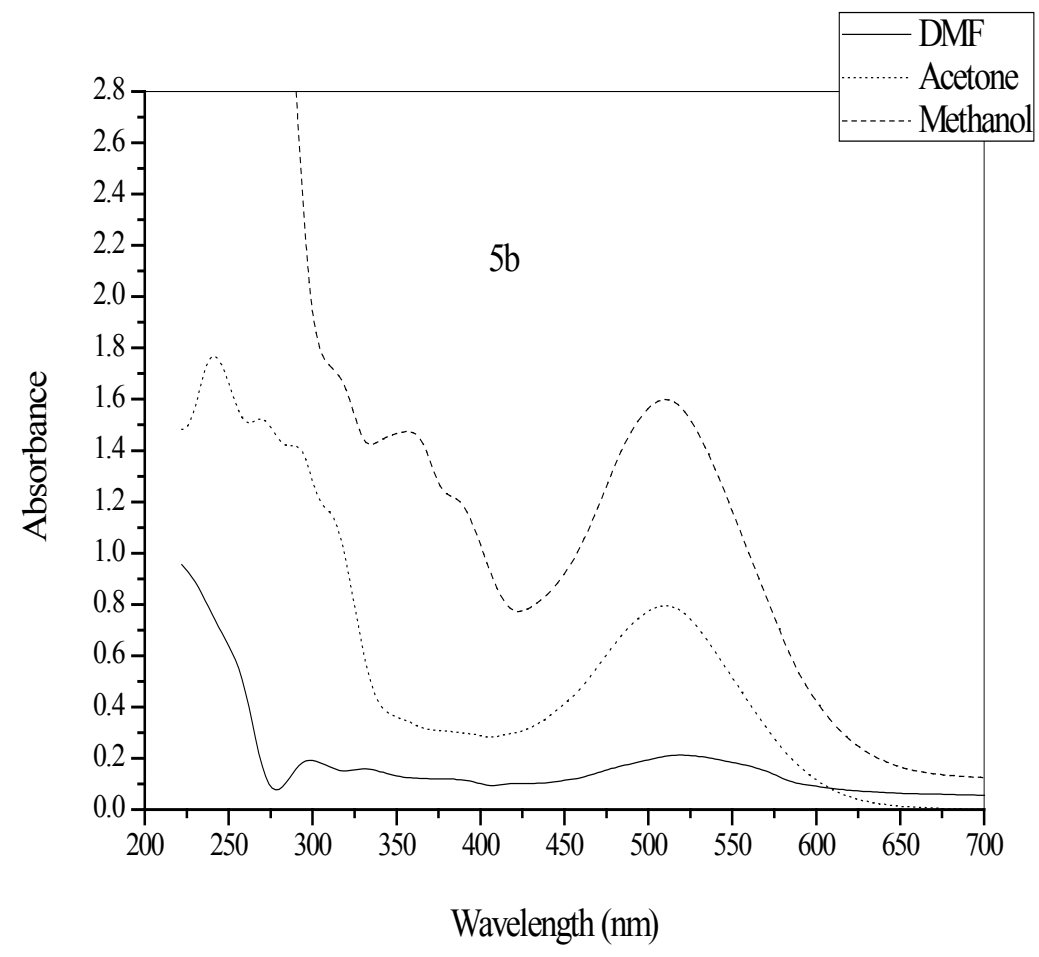

Fig. 1(b). UV-visible absorption spectra of dye 5 b. 


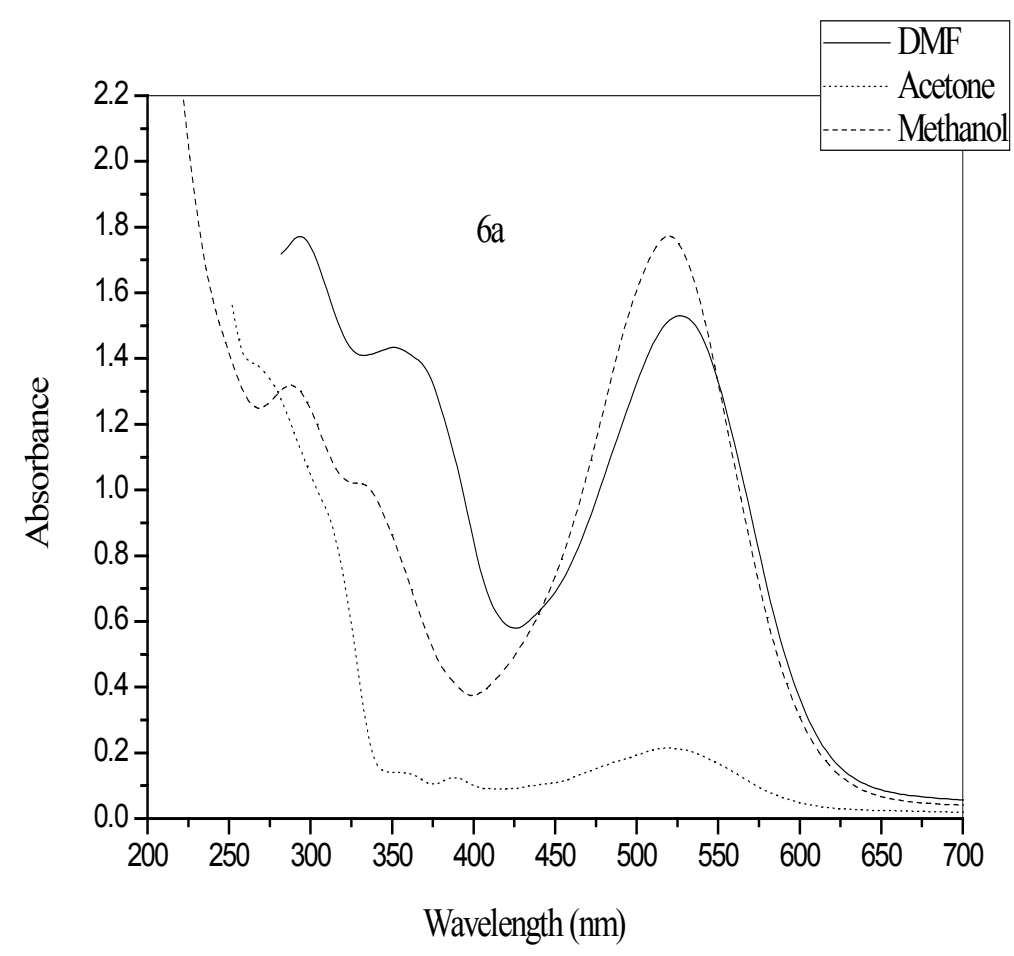

Fig. 1(c). UV-visible absorption spectra of dye 6a.

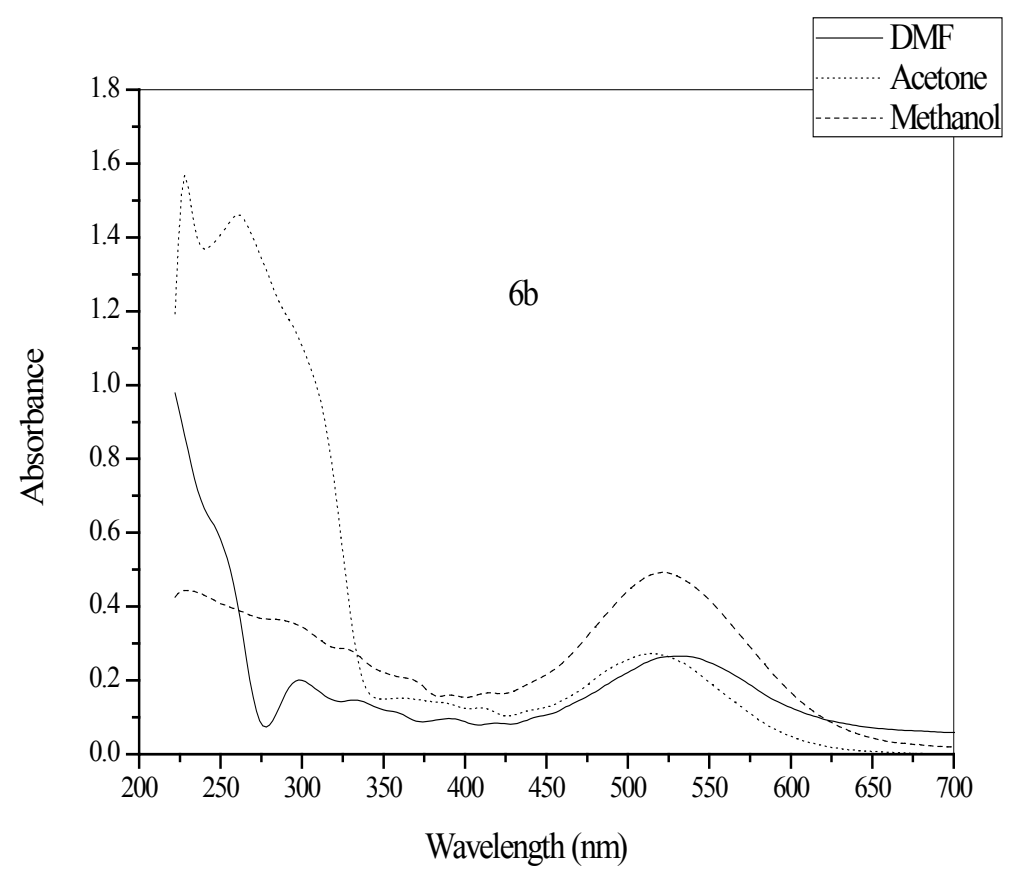

Fig. 1(d). UV-visible absorption spectra of dye $6 \mathrm{~b}$. 


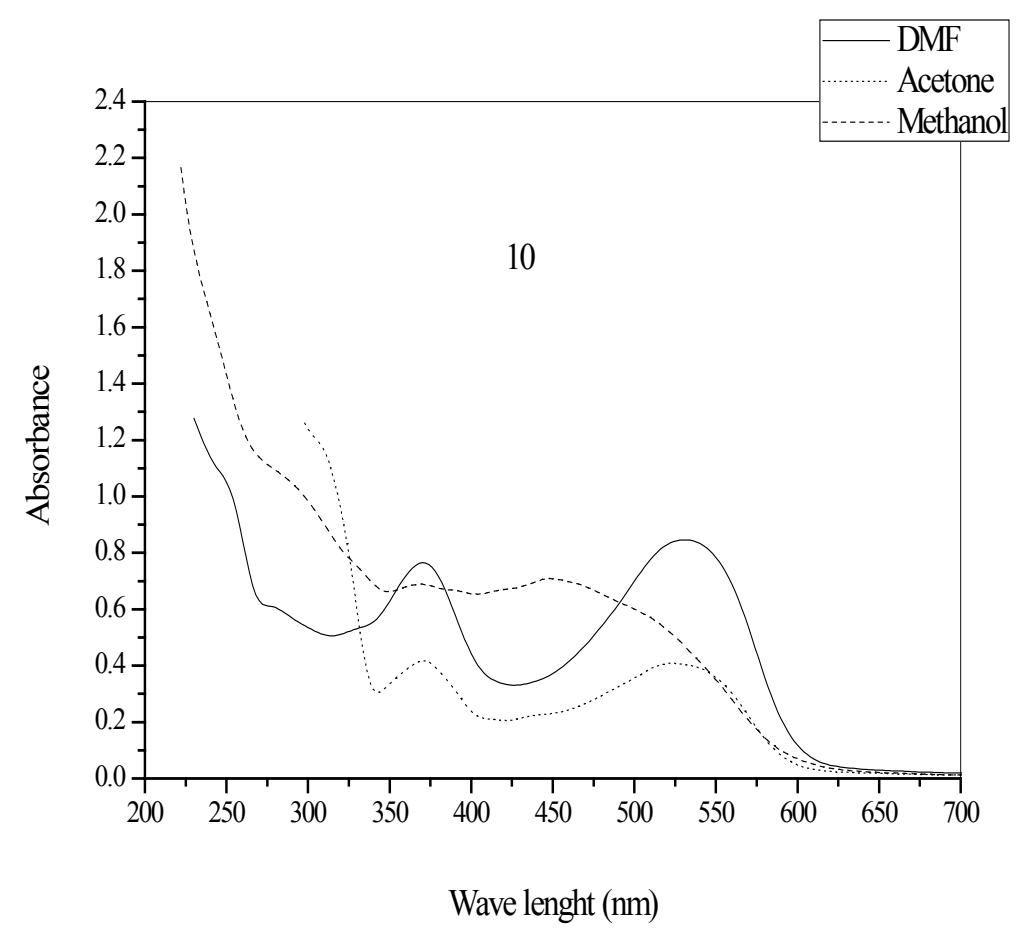

Fig. 2(a). UV-visible absorption spectra of dye 10.

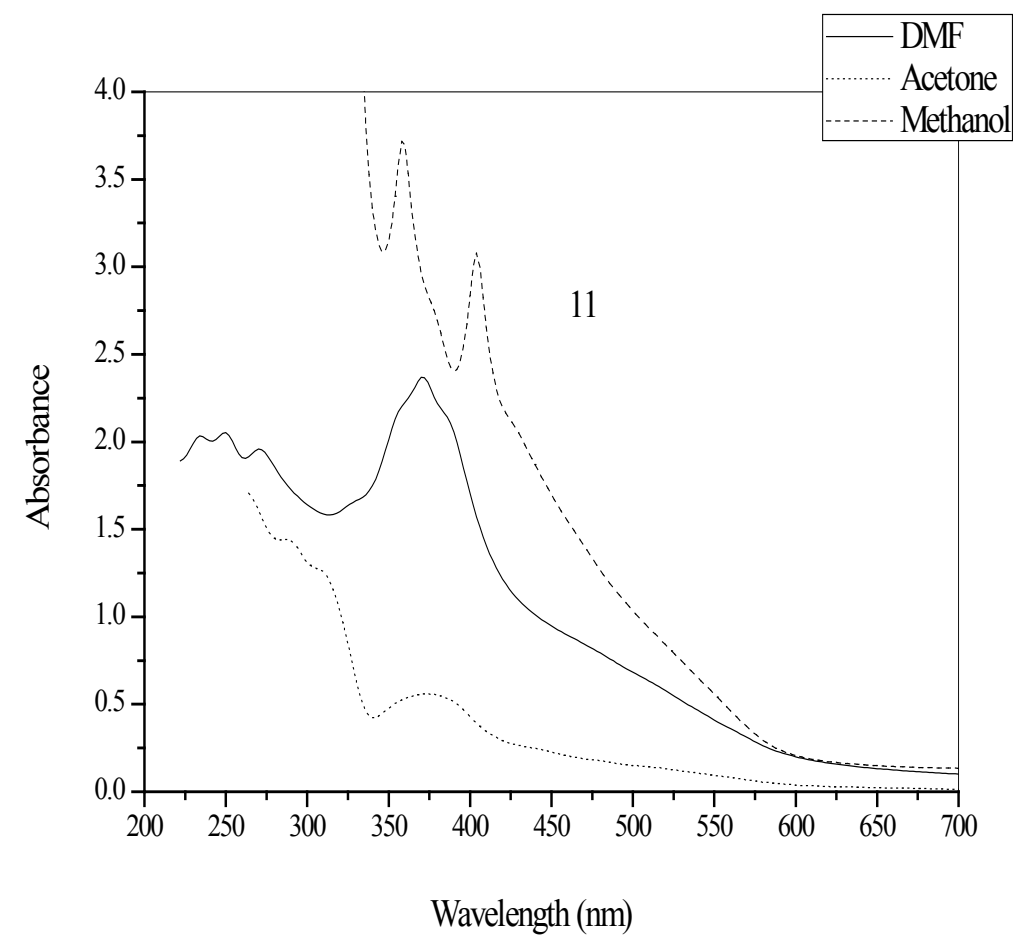

Fig. 2(b). UV-visible absorption spectra of dye 11. 


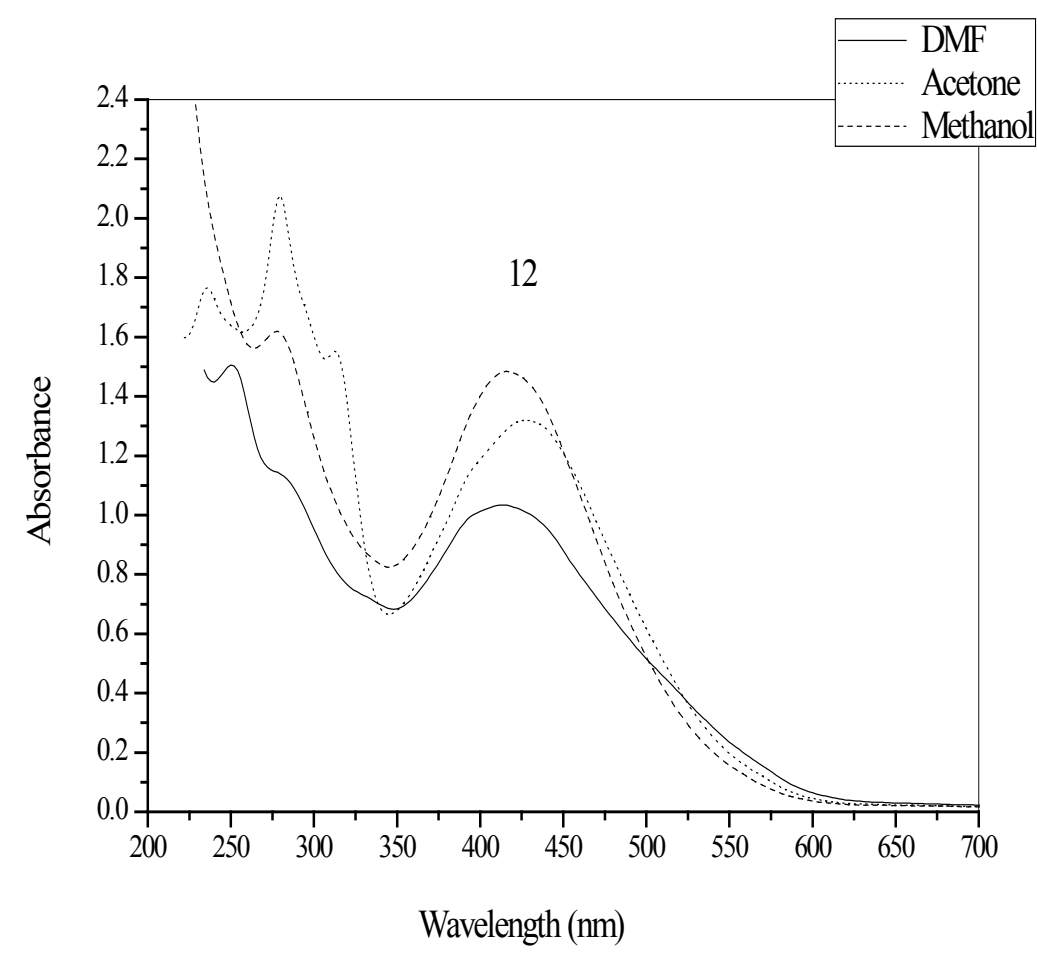

Fig. 2(c). UV-visible absorption spectra of dye 12.

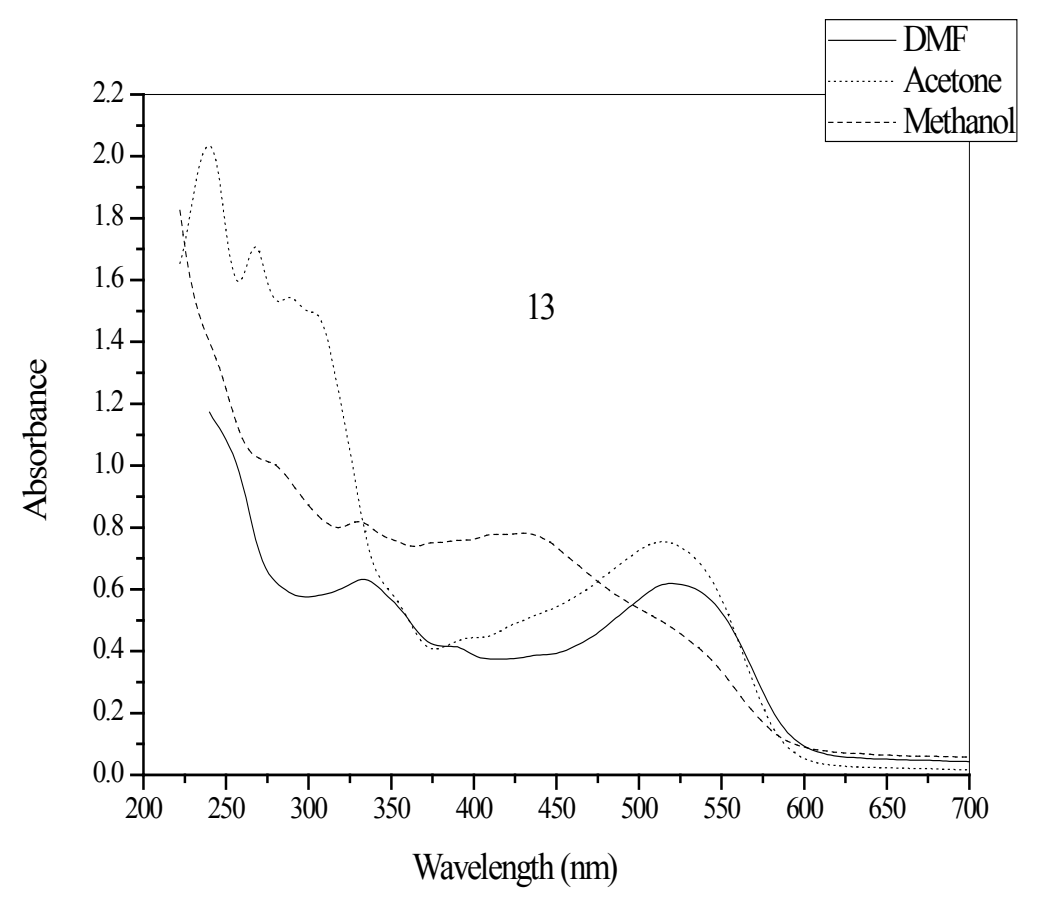

Fig. 2(d). UV-visible absorption spectra of dye 13. 


\section{Experimental}

Melting points (uncorrected) were measured on Gallenkamp electric melting point apparatus. Infrared spectra were recorded on a Nicolet 5000 FT-IR spectrophotometer ( $\mathrm{KBr}$ disk). The ${ }^{1} \mathrm{H}$ NMR spectra were measured on Bruker WP (400 $\mathrm{MHz}$ ) in DMSO- $\mathrm{d}_{6}$ as solvent, using TMS as an internal reference. Mass spectra were recorded on Quadrupole GC/MS Thermo Scientific Focus/ DSQII at $70 \mathrm{eV}$.

(1) General method for the preparation of 2-((2-amino-4-phenyl-thiazol-5-yl)azo)-4,5, 6, 7tetrahydrobenzo[b]thiophenes 5 and 6

2-Aminothiophene derivative $1 \mathrm{a}$ or $1 \mathrm{~b}$ (5 mmol) has been dissolved by warming in $15 \mathrm{~mL}$ acetic acid/propionic acid mixture $(2: 1)$ and then cooled to $0-5^{\circ} \mathrm{C}$ in ice bath. The liquor was added in portions during thirty minutes to a cold solution $\left(0-5^{\circ} \mathrm{C}\right)$ of freshly prepared nitrosyl sulphuric acid by dissolving portions of sodium nitrite $(0.35$ g) with stirring in $4.2 \mathrm{~mL}$ conc. $\mathrm{H} 2 \mathrm{SO} 4$. The freshly diazonium sulphate solution that obtained underwent dropwise addition to a cold solution of 2-aminothiazole derivative 3 and/or 4 ( $5 \mathrm{mmol})$ in $30 \mathrm{~mL}$ ethyl alcohol and $3.0 \mathrm{~g}$ sodium acetate. After stirring of the mixture for two hours at $0-5^{\circ} \mathrm{C}$, the resulting precipitate was filtered and recrystallized from dioxane.

Ethyl 2-((2-amino-4-phenylthiazol-5-yl)azo) -4, 5, 6, 7-tetrahydrobenzo[b] thiophene-3carboxylate (5a)

Deep violet powder, yield $=72.8 \%$, m.p. $=$ 259-260 ${ }^{\circ} \mathrm{C}$. IR (KBr): $\mathrm{v} / \mathrm{cm}^{-1}=3318,3264\left(\mathrm{NH}_{2}\right)$, $1707($ Et-O-C $=\mathrm{O}) .{ }^{1} \mathrm{H}$ NMR $\left(\mathrm{CDCl}_{3}\right): \delta / \mathrm{ppm}=$ $1.44\left(\mathrm{t}, \mathrm{J}=7.00 \mathrm{~Hz}, 3 \mathrm{H},-\mathrm{O}-\mathrm{CH}_{2}-\mathrm{CH}_{3}\right), 1.82-1.84$ $\left(\mathrm{m}, 4 \mathrm{H}, 2 \mathrm{CH}_{2}\right), 2.74-2.80(\mathrm{~m}, 4 \mathrm{H}, 2 \mathrm{CH} 2), 4.40$ (q, $\left.\mathrm{J}=7.06 \mathrm{~Hz}, 2 \mathrm{H},-\mathrm{O}-\mathrm{CH}_{2}-\mathrm{CH}_{3}\right), 6.41\left(\mathrm{~s}, 2 \mathrm{H}, \mathrm{NH}_{2}\right)$, 7.42-7.49 (m, 3H, Ar-H), 8.20 (d, J = 7.60 Hz, 2H, Ar-H). Analytical calculations for $\mathrm{C}_{20} \mathrm{H}_{20} \mathrm{~N}_{4} \mathrm{O}_{2} \mathrm{~S}_{2}$ (412): C, 58.23; H, 4.89; N, 13.58\%. Found: C, $58.11 ; \mathrm{H}, 4.87$; N $13.67 \%$.

2-((2-Amino-4-phenylthiazol-5-yl)azo)-4, 5, 6, 7tetrahydrobenzo[b] thiophene-3-carboxamide (5b)

Deep violet powder, yield $=52 \%$, m.p. above $300^{\circ} \mathrm{C}$. IR (KBr): $\mathrm{v} / \mathrm{cm}^{-1}=3425,3347,3268$ $\left(\mathrm{NH}_{2}\right), 1660\left(\mathrm{C}=\mathrm{O}\right.$, amide). ${ }^{1} \mathrm{H}$ NMR $\left(\mathrm{DMSO}-\mathrm{d}_{6}\right)$ : $\delta / \mathrm{ppm}=1.78-1.80\left(\mathrm{~m}, 4 \mathrm{H}, 2 \mathrm{CH}_{2}\right), 2.71-2.75(\mathrm{~m}$, $\left.4 \mathrm{H}, 2 \mathrm{CH}_{2}\right), 6.48\left(\mathrm{~s}, 2 \mathrm{H}, \mathrm{NH}_{2}\right), 7.40-7.51(\mathrm{~m}, 3 \mathrm{H}$, Ar-H), 7.70 (s, 2H, NH $), 8.23$ (d, J = $7.20 \mathrm{~Hz}$, $2 \mathrm{H}, \mathrm{Ar}-\mathrm{H})$. Mass analysis: $(\mathrm{m} / \mathrm{z}, \%)=383(\mathrm{M}+$, $64.7 \%$ ). Analytical calculations for $\mathrm{C}_{18} \mathrm{H}_{17} \mathrm{~N}_{5} \mathrm{OS}_{2}$
(383): C, 56.38; H, 4.47; N, 18.26\%. Found: C, $56.16 ; \mathrm{H}, 4.51 ; \mathrm{N}, 18.37 \%$.

Ethyl 2-((2-(methylamino)-4-phenylthiazol-5-yl) diazenyl)-4, 5, 6, 7-tetrahydrobenzo-[b]thiophene3-carboxylate (6a)

Deep violet powder, yield $=55 \%$, m.p. $=192$ $194^{\circ} \mathrm{C}$. IR (KBr): v/cm ${ }^{-1}=3434(\mathrm{~N}-\mathrm{H}), 1688$ $(\mathrm{Et}-\mathrm{O}-\mathrm{C}=\mathrm{O}) .1 \mathrm{H} \mathrm{NMR}\left(\mathrm{CDCl}_{3}\right): \delta / \mathrm{ppm}=1.35$ $\left(\mathrm{t}, \mathrm{J}=7.05 \mathrm{~Hz}, 3 \mathrm{H},-\mathrm{O}-\mathrm{CH}_{2}-\mathrm{CH}_{3}\right), 1.82-1.83(\mathrm{~m}$, $\left.4 \mathrm{H}, 2 \mathrm{CH}_{2}\right), 2.75-2.81\left(\mathrm{~m}, 4 \mathrm{H}, 2 \mathrm{CH}_{2}\right), 3.10(\mathrm{~s}$, $\left.3 \mathrm{H}, \mathrm{N}-\mathrm{CH}_{3}\right), 4.36\left(\mathrm{q}, \mathrm{J}=7.10 \mathrm{~Hz}, 2 \mathrm{H},-\mathrm{O}-\mathrm{CH}_{2}-\right.$ $\left.\mathrm{CH}_{3}\right), 7.46-7.52(\mathrm{~m}, 4 \mathrm{H}, 3 \mathrm{Ar}-\mathrm{H}$ and $\mathrm{NH}), 8.21$ (d, $\mathrm{J}=7.60 \mathrm{~Hz}, 2 \mathrm{H}$, Ar-H). Analytical calculations for $\mathrm{C}_{21} \mathrm{H}_{22} \mathrm{~N}_{4} \mathrm{O}_{2} \mathrm{~S}_{2}$ (426): C, 59.13; $\mathrm{H}, 5.20 ; \mathrm{N}$, $13.14 \%$. Found: C, 59.36; H, 5.26; N, $13.22 \%$.

2-((2-(Methylamino)-4-phenylthiazol-5-yl) azo)-4, 5, 6, 7-tetrahydrobenzo[b]-thiophene-3carboxamide (6b):

Deep violet powder, yield $=57 \%$, m.p. $=249$ $250^{\circ} \mathrm{C}$. IR (KBr): $\mathrm{v} / \mathrm{cm}^{-1}=3369,3286(\mathrm{NH}$ and $\left.\mathrm{NH}_{2}\right), 1660(\mathrm{C}=\mathrm{O}$, amide). 1H NMR (DMSO-d 6 ): $\delta / \mathrm{ppm}=1.71-1.75\left(\mathrm{~m}, 4 \mathrm{H}, 2 \mathrm{CH}_{2}\right), 2.71-2.74(\mathrm{~m}$, $\left.4 \mathrm{H}, 2 \mathrm{CH}_{2}\right), 3.04\left(\mathrm{~s}, 3 \mathrm{H}, \mathrm{N}-\mathrm{CH}_{3}\right), 7.47-7.56(\mathrm{~m}, 4 \mathrm{H}$, $3 \mathrm{Ar}-\mathrm{H}$ and $\mathrm{NH}), 7.70\left(\mathrm{~s}, 2 \mathrm{H}, \mathrm{CONH}_{2}\right), 8.22$ (d, J $=7.60 \mathrm{~Hz}, 2 \mathrm{H}, \mathrm{Ar}-\mathrm{H})$. Analytical calculations for $\mathrm{C}_{19} \mathrm{H}_{19} \mathrm{~N}_{5} \mathrm{OS}_{2}$ (397): C, 57.41; H, 4.82; N, 17.62\%. Found: C, 57.54; H, 4.89; N, 17.68\%.

(2) Synthesis of ethyl 2-(1-mercapto-3-oxo1-(phenylamino)but-1-en-2-ylazo)-4, 5, 6, 7tetrahydrobenzo[b]thiophene-3-carboxylate (8)

2-Aminothiophene derivative 1 a $(10 \mathrm{mmol}$, $2.25 \mathrm{~g}$ ) has been dissolved by warming in $30 \mathrm{~mL}$ acetic acid/propionic acid mixture $(2: 1)$ and then cooled to $0-5^{\circ} \mathrm{C}$ in ice bath. The liquor was added in portions during thirty minutes to a cold solution $\left(0-5^{\circ} \mathrm{C}\right)$ of freshly prepared nitrosyl sulphuric acid by dissolving portions of sodium nitrite $(0.7 \mathrm{~g})$ with stirring in $8.4 \mathrm{~mL}$ conc. $\mathrm{H}_{2} \mathrm{SO}_{4}$. The freshly diazonium sulphate solution that obtained underwent dropwise addition to a cold solution of 2-acetyl-3-oxo-N-phenylbutanethioamide (7) (10 mmol, $2.35 \mathrm{~g}$ ) in $50 \mathrm{~mL}$ ethyl alcohol and $6.0 \mathrm{~g}$ sodium acetate. After stirring of the mixture for two hours at $0-5^{\circ} \mathrm{C}$, the resulting precipitate was filtered and recrystallized from acetic acid.

Deep red crystals, yield $=45.2 \%$, m.p. $=138$ $140^{\circ} \mathrm{C}$. IR (KBr): $\mathrm{v} / \mathrm{cm}^{-1}=3443(\mathrm{~N}-\mathrm{H}), 1705($ Et$\mathrm{O}-\mathrm{C}=\mathrm{O}), 1660(\mathrm{C}=\mathrm{O}) .1 \mathrm{H} \mathrm{NMR}\left(\mathrm{CDCl}_{3}\right): \delta / \mathrm{ppm}$ $=1.39\left(\mathrm{t}, \mathrm{J}=7.20 \mathrm{~Hz}, 3 \mathrm{H}, \mathrm{O}-\mathrm{CH}_{2}-\mathrm{CH}_{3}\right), 1.79-1.84$ $\left(\mathrm{m}, 4 \mathrm{H},\left(-\mathrm{CH}_{2}-\mathrm{CH}_{2}-\right), 2.11(\mathrm{~s}, 1 \mathrm{H},-\mathrm{SH}), 2.59\right.$ (s, $\left.3 \mathrm{H}, \mathrm{COCH}_{3}\right), 2.66(\mathrm{t}, \mathrm{J}=5.00 \mathrm{~Hz}, 2 \mathrm{H},-\mathrm{CH} 2-)$, $2.82\left(\mathrm{t}, \mathrm{J}=5.60 \mathrm{~Hz}, 2 \mathrm{H},-\mathrm{CH}_{2}-\right), 4.43(\mathrm{q}, \mathrm{J}=7.06$ 
$\left.\mathrm{Hz}, 2 \mathrm{H}, \mathrm{O}-\mathrm{CH}_{2}-\mathrm{CH}_{3}\right), 7.28-7.70$ (m, 5H, Ar-H), $13.32(\mathrm{~s}, 1 \mathrm{H}, \mathrm{NH})$. Analytical calculations for $\mathrm{C}_{21} \mathrm{H}_{23} \mathrm{~N}_{3} \mathrm{O}_{3} \mathrm{~S}_{2}$ (429): C, 58.72; H, 5.40; N, 9.78\%. Found: C, 58.94; H, 5.48; N, 9.91\%.

(3) Synthesis of ethyl 2-((5-substituted-4-methylthiophen-3-yl)azo)-4,5,6,7-tetrahydrobenzo[b] thiophene-3-carboxylates 10-13

To a hot solution of 2-acetyl-2-thienylazothioacetanilide derivative 8 ( $1 \mathrm{mmol}, 0.42 \mathrm{~g}$ ) in 30 $\mathrm{mL}$ ethyl alcohol, $1 \mathrm{mmol}$ of the appropriate alphahalogenated reagents (namely: chloroacetone, phenacyl chloride, ethyl chloroacetate and/or chloroacetonitrile) and $0.5 \mathrm{~mL}$ triethylamine were added. The reaction was proceeded by heating under reflux for 3 hours. The solid that formed on cooling to $25^{\circ} \mathrm{C}$ was filtered and dried to pick up the targeted thienylazo-thiophene dyes 10, 11, 12 and 13 .

Ethyl 2-((5-acetyl-4-methyl-2-(phenylamino) thiophen-3-yl)azo)-4,5,6,7-tetrahydro-benzo[b] thiophene-3-carboxylate (10)

Violet powder, yield $=82 \%$, m.p. $=181-$ $182^{\circ} \mathrm{C}$. IR (KBr): v/cm ${ }^{-1}=3434(\mathrm{~N}-\mathrm{H}), 1688($ Et$\mathrm{O}-\mathrm{C}=\mathrm{O}), 1643(\mathrm{C}=\mathrm{O})$. 1H NMR $\left(\mathrm{CDCl}_{3}\right): \delta / \mathrm{ppm}$ $=1.35\left(\mathrm{t}, \mathrm{J}=7.00 \mathrm{~Hz}, 3 \mathrm{H}, \mathrm{O}-\mathrm{CH}_{2}-\mathrm{CH}_{3}\right), 1.82-$ $1.83\left(\mathrm{~m}, 4 \mathrm{H},\left(-\mathrm{CH}_{2}-\mathrm{CH}_{2}-\right), 2.50(\mathrm{~s}, 3 \mathrm{H}\right.$, thiophene$\left.\mathrm{CH}_{3}\right), 2.65\left(\mathrm{~s}, 3 \mathrm{H}, \mathrm{COCH}_{3}\right), 2.72(\mathrm{t}, \mathrm{J}=5.60 \mathrm{~Hz}$, $\left.2 \mathrm{H}, \mathrm{CH}_{2}\right), 2.82\left(\mathrm{t}, \mathrm{J}=5.60 \mathrm{~Hz}, 2 \mathrm{H}, \mathrm{CH}_{2}\right), 4.32(\mathrm{q}$, $\mathrm{J}=7.06 \mathrm{~Hz}, 2 \mathrm{H}, \mathrm{O}-\mathrm{CH} 2-\mathrm{CH} 3), 7.18-7.65$ (m, 5H, Ar-H), 13.14 (s, 1H, NH). Analytical calculations for $\mathrm{C}_{24} \mathrm{H}_{25} \mathrm{~N}_{3} \mathrm{O}_{3} \mathrm{~S}_{2}$ (467): C, 61.65; $\mathrm{H}, 5.39 ; \mathrm{N}$, 8.99\%. Found: C, 61.78; H, 5.32; N, 9.08\%.

Ethyl 2-((5-benzoyl-4-methyl-2-(phenylamino) thiophen-3-yl)diazenyl)-4, 5, 6, 7-tetrahydrobenzo[b] thiophene-3-carboxylate (11):

Violet powder, yield $=56 \%$, m.p. $194-195^{\circ} \mathrm{C}$. IR (KBr): v/cm ${ }^{-1}=3444(\mathrm{~N}-\mathrm{H}), 1707(\mathrm{Et}-\mathrm{O}-\mathrm{C}=\mathrm{O})$, $1656(\mathrm{C}=\mathrm{O}) .{ }^{1} \mathrm{H}$ NMR $\left(\mathrm{DMSO}_{-} \mathrm{d}_{6}\right): \delta / \mathrm{ppm}=1.34$ $\left(\mathrm{t}, \mathrm{J}=7.00 \mathrm{~Hz}, 3 \mathrm{H}, \mathrm{O}-\mathrm{CH}_{2}-\mathrm{CH}_{3}\right), 1.81-1.83$ (m, $4 \mathrm{H},\left(-\mathrm{CH}_{2}-\mathrm{CH}_{2}-\right), 2.22\left(\mathrm{~s}, 3 \mathrm{H}\right.$, thiophene- $\left.\mathrm{CH}_{3}\right)$, $2.72\left(\mathrm{t}, \mathrm{J}=5.60 \mathrm{~Hz}, 2 \mathrm{H}, \mathrm{CH}_{2}\right), 2.81(\mathrm{t}, \mathrm{J}=5.60$ $\mathrm{Hz}, 2 \mathrm{H}, \mathrm{CH} 2), 4.31$ (q, J = 7.06 Hz, 2H, O-CH2CH3), 7.02-7.85 (m, 10H, Ar-H), 14.24 (s, 1H, NH). Mass analysis: $(\mathrm{m} / \mathrm{z}, \%)=529(\mathrm{M}+, 64.4 \%)$. Analytical calculations for $\mathrm{C}_{29} \mathrm{H}_{27} \mathrm{~N}_{3} \mathrm{O}_{3} \mathrm{~S}_{2}$ (529): C, 65.76; H, 5.14; N, 7.93\%. Found: C, 65.95; H, $5.08 ; \mathrm{N}, 7.81 \%$.

Ethyl 2-((5-(ethoxycarbonyl)-4-methyl-2(phenylamino) thiophen-3-yl)azo)-4,5,6,7tetrahydrobenzo[b] thiophene-3-carboxylate (12)

Brown powder, yield $=69 \%$, m.p. $174-175^{\circ} \mathrm{C}$. IR (KBr): v/cm ${ }^{-1}=3448(\mathrm{~N}-\mathrm{H}), 1707($ Et-O-C=O), $\left.1684(\text { Et-O-C=O). 1H NMR (DMSO-d })_{6}\right): \delta / p p m$ $=1.28\left(\mathrm{t}, \mathrm{J}=6.48 \mathrm{~Hz}, 3 \mathrm{H},-\mathrm{O}-\mathrm{CH}_{2}-\mathrm{CH}_{3}\right), 1.34(\mathrm{t}$, $\left.\mathrm{J}=7.00 \mathrm{~Hz}, 3 \mathrm{H}, \mathrm{O}-\mathrm{CH}_{2}-\mathrm{CH}_{3}\right), 1.81-1.83(\mathrm{~m}, 4 \mathrm{H}$, $\left(-\mathrm{CH}_{2}-\mathrm{CH}_{2}-\right), 2.56\left(\mathrm{~s}, 3 \mathrm{H}\right.$, thiophene- $\left.\mathrm{CH}_{3}\right), 2.72$ $\left(\mathrm{t}, \mathrm{J}=5.60 \mathrm{~Hz}, 2 \mathrm{H},-\mathrm{CH}_{2}-\right), 2.81(\mathrm{t}, \mathrm{J}=5.60 \mathrm{~Hz}$, $\left.2 \mathrm{H},-\mathrm{CH}_{2}-\right), 4.28\left(\mathrm{q}, \mathrm{J}=6.60 \mathrm{~Hz}, 2 \mathrm{H},-\mathrm{O}-\mathrm{CH}_{2}-\right.$ $\left.\mathrm{CH}_{3}\right), 4.32\left(\mathrm{q}, \mathrm{J}=7.06 \mathrm{~Hz}, 2 \mathrm{H}, \mathrm{O}-\mathrm{CH}_{2}-\mathrm{CH}_{3}\right.$ ), 7.20-7.68 (m, 5H, Ar-H), 14.54 (s, 1H, NH). Mass analysis: $(\mathrm{m} / \mathrm{z}, \%)=497(\mathrm{M}+, 82.7 \%)$. Analytical calculations for $\mathrm{C}_{25} \mathrm{H}_{27} \mathrm{~N}_{3} \mathrm{O}_{4} \mathrm{~S}_{2}$ (497): C, 60.34; H, 5.47; N, 8.44\%. Found: C, 60.48; H, 5.55; N, $8.36 \%$

Ethyl 2-((5-cyano-4-methyl-2-(phenylamino) thiophen-3-yl)azo)-4, 5, 6, 7-tetrahydro-benzo[b] thiophene-3-carboxylate (13)

Brown powder, yield $=66 \%$, m.p. $166-168^{\circ} \mathrm{C}$. IR (KBr): v/cm ${ }^{-1}=3432(\mathrm{~N}-\mathrm{H}), 2199(\mathrm{C} \equiv \mathrm{N}), 1701$ $(\mathrm{Et}-\mathrm{O}-\mathrm{C}=\mathrm{O}) .{ }^{1} \mathrm{H}$ NMR $\left(\mathrm{CDCl}_{3}\right): \delta / \mathrm{ppm}=1.34(\mathrm{t}$, $\left.\mathrm{J}=7.20 \mathrm{~Hz}, 3 \mathrm{H}, \mathrm{O}-\mathrm{CH}_{2}-\mathrm{CH}_{3}\right), 1.82-1.84(\mathrm{~m}, 4 \mathrm{H}$, $\left(-\mathrm{CH}_{2}-\mathrm{CH}_{2}-\right), 2.43\left(\mathrm{~s}, 3 \mathrm{H}\right.$, thiophene- $\left.\mathrm{CH}_{3}\right), 2.71(\mathrm{t}$, $\left.\mathrm{J}=5.20 \mathrm{~Hz}, 2 \mathrm{H},-\mathrm{CH}_{2}-\right), 2.82(\mathrm{t}, \mathrm{J}=5.20 \mathrm{~Hz}, 2 \mathrm{H}$, $\left.-\mathrm{CH}_{2}-\right), 4.31\left(\mathrm{q}, \mathrm{J}=7.06 \mathrm{~Hz}, 2 \mathrm{H}, \mathrm{O}-\mathrm{CH}_{2}-\mathrm{CH}_{3}\right)$, 7.21-7.54 (m, 5H, Ar-H), 13.47 (s, 1H, NH). Analytical calculations for $\mathrm{C}_{23} \mathrm{H}_{22} \mathrm{~N}_{4} \mathrm{O}_{2} \mathrm{~S}_{2}$ (450): C, 61.31; H, 4.92; N, 12.43\%. Found: C, 61.11; $\mathrm{H}, 4.89$; N, $12.47 \%$.

\section{References}

1. Zollinger, H. Color chemistry. Synthesis, properties and application of organic dyes. Weincheim: Verlag Chemie (1987).

2. Christie, R. M. Colour chemistry. Cambridge: The Royal Society of Chemistry, 26-50 (2001).

3. Elgemeie, G. H., Helal, M. H.; El-Sayed, H. M. Recent trends in synthesis and application of nitrogen heterocyclic azo dyes. Pigment \& Resin Technology 30, 210-228 (2001).

4. Koh, J., Greaves, A. J. Synthesis and application of an alkali-clearable azo disperse dye containing a fluorosulfonyl group and analysis of its alkalihydrolysis kinetics. Dyes Pigm. 50, 117-126 (2001).

5. Shaban, E.; Nassar, S. H.; Shabban, S.; Gaffer, H. E. Synthesis and antibacterial activity of some new azo disperse dyes containing selenium and their application in polyester printing. Egypt. J. Chem. 60, 73-78 (2017).

6. Uscumlic, G. S., Mijin, D. Z., Valentic, N. V., Vajs V. V., Susic B. M. Substituent and solvent effects on the UV/Vis absorption spectra of 5-(4-substituted arylazo)-6-hydroxy-4-methyl-

J.Text.Color. Polym. Sci., Vol. 15, No.1(2018) 
3-cyano-2-pyridones. Chem. Phys. Lett. 397, $148-53$ (2004).

7. Raposo, M. M. M.; Sousa, A. M. R. C.; Fonseca, A. M. C.; Kirsch, G. Thienylpyrrole azo dyes: Synthesis, solvatochromic and electrochemical properties. Tetrahedron 61, 8249-56 (2005).

8. Takagi, K.; Mizuno, A.; Iwamoto, H.; Kawashima, S.; Nishida, S.; Hashikawa, T. Syntheses and absorption spectra of new azo dyes containing an azulene ring. Dyes Pigments 26, 51-60 (1994).

9. ElKholy, Y. M.;Abd El-Hafiz, S.A. Polyfunctionally pyrazole azo dyes: Synthesis and application. Pigment Resin Technol. 23, 3-5 (1994).

10. Mishra, A.; Ma, C. Q.; Bauerle, P. Functional oligothiophenes: Molecular design for multidimensional nanoarchitectures and their applications. Chem. Rev. 109, 1141-1276 (2009).

11. Gather, M. C.; Kohnen, A.; Meerholz, K. White organic light-emitting diodes. Adv. Mater. 23, 233 248 (2011)

12. Radwan, A. S.; Makhlouf, M. M.; Abdel-Latif, E. Azothiophene dyes nanotubes structure based thin films: Synthesis, structural and optical characterization toward application in dyesensitized solar cells. Dyes Pigment. 134, 516-525 (2016).

13. Nazim, M.; Ameen, S.; Akhtar, M. S.; Shin, H.S. D- $\pi-A-\pi-D$ type thiazolo[5,4-d]-thiazole-core organic chromophore and graphene modified PEDOT:PSS buffer layer for efficient bulk heterojunction organic solar cells. Solar Energy 171, 366-373 (2018).
14. Mahmood, A.; Hu, J.; Tang, A.; Chen, F.; Wang, X.; Zhou E. A novel thiazole based acceptor for fullerene-free organic solar cells. Dyes Pigments 149, 470-474 (2018).

15. Mohareb, R. M.; Manhi, F. M. Reaction of ethyl 2-diazo-4,5,6,7-tetrahydro-benzo[b]thiophene3-carboxylate with 3-iminobutyro-nitrile: Synthesis of pyridazines, thiophenes, and their fused derivatives. Heteroatom Chem. 11, 403-412 (2000).

16. Gewald, K.; Schinke, E.; Böttcher, H. Heterocyclen aus $\mathrm{CH} \square$ aciden nitrilen, VIII. 2 $\square$ Amino $\square$ thiophene aus methylenaktiven nitrilen, carbonyl verbindungen und schwefel. Chem. Ber. 99, 94-100 (1966).

17. DeBolt, S. E.; Kollman, P. A. A theoretical examination of solvatochromism and solutesolvent structuring in simple alkyl carbonyl compounds. Simulations using statistical mechanical free energy perturbation methods. J. Am. Chem. Soc. 112, 7515-7524 (1990).

18. Fox, T.; Rösch, N. The calculation of solvatochromic shifts: The $n-\pi *$ transition of acetone. Chem. phys. Lett. 191, 33-37 (1992).

19. Georg, H. C.; Coutinho, K.; Canuto, S. Effects on the UV-visible absorption spectrum of benzophenone in water: A combined Monte Carlo quantum mechanics study including solute polarization. J. Chem. Physics 126, 034507 (2007).

20. Zakerhamidi, M. S.; Ghanadzadeh, A.; Moghadam, M. Solvent effects on the UV/visible absorption spectra of some aminoazobenzene dyes. Chem. Sci. Trans. 1, 1-8 (2012). 


\title{
أثثيرات المذيب على أطياف امتصاص الأثنعة المرئية و الفوق البنفسجية لبعض أصباغ أنواغ ثينيل أزو-ثيازول و ثينيل أزوائثيوفين الجديدة \\ إيهاب عبد اللطيف*، أسماء محمد منصور و إبراهيم عبد الجليل

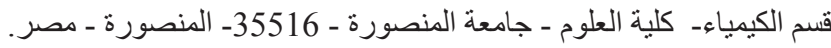

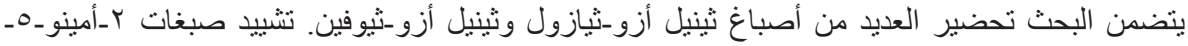

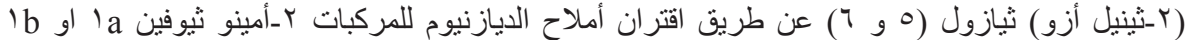

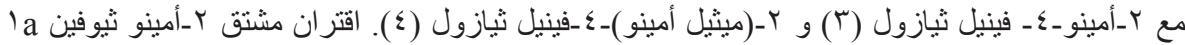

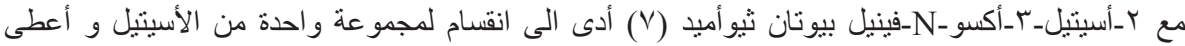

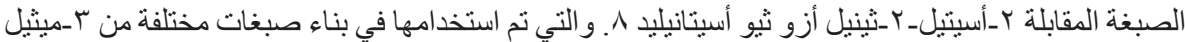

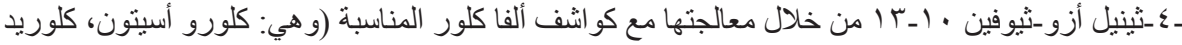

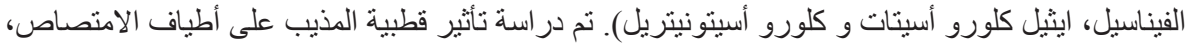
وكذللك العلاقة بين تركيب الأصباغ و الامتصاص في المنطقة المرئية و الأشعة فوق البنفية البنسجية.
\end{abstract}

البريد الالكترونى: ehabattia00@gmx.net 